\title{
Strategic instrument or social institution: Rationalized myths of the university in stakeholder perceptions of higher education reform in Poland
}

\author{
Marta A. Shaw \\ Institute of Public Affairs, Department of Management and Social Communication, Jagiellonian University, ul Łojasiewicza 4, R 3.317, 30-348, Kraków, Poland
}

\section{A R T I C L E I N F O}

\section{Keywords:}

Educational policy

Educational reform

European universities

Autopoiesis

University autonomy

Higher education governance

Poland

\begin{abstract}
A B S T R A C T
European universities have come under reform pressures to make them instruments of social and economic development, compromising their earlier status as socially buffered institutions. The aim of this paper was to investigate the hypothesis that tensions and inconsistencies in recent higher education reforms in Poland trace back to a fundamental conflict between institutional and instrumental visions of the university. Findings suggest an intersection of "rationalized myths" that locks the university sector in a "corset" experienced by stakeholders more like a return to the Soviet past than the way of a better future. Seen through the lens of second-order systems theory, these findings problematize the assumption that the historically grounded institution of the university can be re-oriented as an instrument for achieving state priorities with a mere balance of carrots and state-of-the-art sticks.
\end{abstract}

\section{Introduction}

With enrollments in post-secondary education across Europe exceeding 60\% (World Bank, 2017), there is hardly a European family whose future is unaffected by the fate of the university and its institutional cousins or descendants. Since the 1960s, with the rising tides of massification, institutions of higher education have become central not just to the future of individuals, but to social and economic development, rendering them "central institutions of human society" (Marginson et al., 2018). In the European Union, governments and the public alike see the university as "one of the few institutions that can help Europe to come out of its current multidimensional crisis" (Gornitzka and Maassen, 2017). In a manner consistent with the understanding of organizations as open systems responsive to change in their environment, European policymakers have attempted to use both incentives and mandates to stimulate universities to produce employable graduates and marketable innovations.

As a result, institutions that have historically functioned as autonomous associations of masters and students, shielded from social and economic pressures (Shaw \& Lenartowicz, 2016), are now inundated with reform efforts to turn them into engines of national and global development (Maassen and Olsen, 2007). Reform initiatives in higher education across Europe have tended to reflect an instrumental vision of the university, which - by the logic of the reformers - should cease to be isolated from industry and society, and instead become "an instrument for shifting national political agendas" (Olsen, 2007, p. 30; Kwiek,
2015, p. 79). This stands in sharp contrast to the institutional vision of the university dating back to medieval times, in which rationally proven knowledge is pursued and disseminated in "a rule-governed community of scholars" (Olsen, 2007, p. 30), protected by the state from the short-term interests of societal interest groups. Ramirez and Tiplic (2014) describe the cultural shift currently facing European universities as being driven by "the triumph of models of the university as socially embedded rationalized organizations," in contrast to a view of universities as "socially buffered and historically grounded institutions" (p. 440).

The current shift has not escaped controversy, as "social disembeddedness" has been a defining quality of the European university since its founding (Krücken, 2003, p. 324). Nowhere in Europe is the sensitive dance of disembeddedness and accountability more evident than in the post-communist states of Central and Eastern Europe, where the notion of higher education as "an instrument for shifting national political agendas" (Olsen, 2007, p. 30) awakens memories of the previous instance of strong state intervention in the inner workings of universities - the communist era. To date, it has not been subject to empirical research how transnational trends in higher education reform intersect with the organizational identities of higher education institutions in states with established academic traditions, where universities served as key instruments in the "state socialist modernization project" (Péteri, 2000, p. 280).

Poland provides a particularly instructive case study. In the period of real socialism, the Polish system of higher education was subjected to

E-mail address: marta.shaw@uj.edu.pl. 
central planning in most aspects of its functioning (Zysiak, 2016) - yet traditional social buffers around universities enabled protection for pockets of academic freedom consistent with the pre-war conception of the university as a self-governing community of scholars (Simonová and Antonowicz, 2006). When the country regained independence, universities won extensive autonomy and returned to a model of academic self-rule, entrenching the institutional vision of the university through an association between national and academic self-determination (Shaw, 2018).

It is not coincidental that even as Polish governments have attempted to shift the legislative framework towards the instrumental blueprint through two waves of reforms in 2010-2011 and 2018-2019, Polish higher education remains as one of the few European holdouts of a governance model approximating the traditional blueprint for "a rulegoverned community of scholars." (Kwiek, 2015; Shaw, 2018). Kwiek (2015) hypothesized on the pages of this journal that at the roots of the tensions observed in Poland might lie "a conflict between the institutional vision of the university shared by the academic community (a value-based 'community of scholars') and the instrumental vision shared by the policy-making community (an externally-driven, national, goal oriented 'organization')" which is in fact a conflict of "fundamental values" (p. 87). This study was an attempt to put Kwiek's (2015) hypothesis to empirical investigation.

The theoretical framework employed in this study drew on secondorder systems theory, where human organizations are conceptualized as complex and living systems, subject to the principle of autopoiesis - a process of continuous and recursive self-production governing all of the system's activities (Luhmann, 2009). As Kwiek (2015) hypothesized a difference in fundamental values held by influential actors belonging to two distinct communities, a systems approach would suggests an investigation of the blueprint or blueprints governing the self-organization of the academic system(s) now subject to external pressure for change. From a systems perspective, what determines the exchange between the academic system and its policy environment is its own blueprint of identity constructed through language - or to use a biological image, the "DNA" governing its self-production (Lenartowicz, 2015). Based on these assumptions, the author of this study sought to examine the distinctions that make up a resistant pattern of organizational identity embedded in public universities' self-description, at a time when these institutions were subject to both mandates and incentives envisioned by policymakers as stimuli towards change. To this end, the research investigated the images and rationalized myths invoked in support of the fundamental values seen as essential to the nature of the university by key players in the system.

This study looks at the governance reforms of the last decade in Polish higher education from the perspective of two groups of leading actors in the system - architects of a reform in 2010/2011 that introduced "fundamentally new rules of the game" following the European blueprint, and leaders of academic institutions charged with implementing the reforms. The article compares their perceptions of the reforms and the "rationalized myths" used to make sense of their meaning. The author also explores possible trajectories for future change and the challenges faced in the process of positioning universities as engines of development for industry and society.

\section{Theoretical framework}

In the past decade, the European policy community passed legislation based on the assumption that with a combination of legislative mandates and a generous infusion of external investments, the academic community can be taught to produce employable graduates and marketable innovations. This approach was consistent with the early understanding of organizations as open systems dependent upon their environment for information and resources (e.g. Von Bertalanffy, 1968). The open systems perspective, conceptualizing change within the organization as a result of a change in the environment, was popularized in management practice by Katz and Kahn (1966), and served as the conceptual foundation of public intervention to finance change in autonomous organizations. Early systems theory, however, failed to account for the mechanisms of inducing and sustaining such change, or to propose conceptually consistent grounds for the evaluation of external interventions (Lenartowicz, 2018).

This challenge taken up by second-order systems theorists, with a significant breakthrough emerging out of Niklas Luhmann's conceptualization of organizations as autopoietic systems. Autopoiesis, a term first used in biology, refers to a system's perpetuation of its own identity pattern. While biological systems perpetuate themselves through material processes, Luhmann (2009) posited that social systems accomplish this by means of communication. Much as a cell's communication with its environment is guided by the cell's own "agenda" encoded in its DNA, the interactions between an organization and its ecosystem are guided by its own survival interests - i.e. what the organization perceives as vital for the generation of its own identity pattern. Therefore, change in the environment will only produce change in an autopoietic social system to the extent that it is perceived as relevant to its own self-generation. External stimuli irrelevant to a system's identity pattern but impossible to ignore will be treated as "perturbations" and mitigated with "compensations" - behaviors aimed at restoring the system's ability to self-perpetuate. Seidl (2016) suggests that lasting organizational change is one that alters a system's identity pattern (p. 113). Lenartowicz (2018) claims that the only change worthy of public resources is not merely one that changes superficial practice, but shifts the pattern of identity embedded in an organization's daily, discursive self-description.

Many believe that the conceptualization of social systems as autopoietic constitutes a major milestone in the development of organization theory, with Magalhaes and Sanchez (2009) going as far as to say that it may become its new unifying framework. This paper attempts to put the autopoietic conceptualization to empirical use in an examination of Kwiek's hypothesis regarding the conflict of fundamental values in Polish higher education. If such conflict of values exists, what are its lines of demarcation - and more importantly, do these lines coincide with the boundaries of recognizably different organizational systems with distinct patterns of identity? Across the different types of public institutions of higher education, are pressures to improve external relevance seen as consistent or inconsistent with their different identity patterns? Is there evidence for change in any of the organizational identity patterns as a result of reform? If the tenets of second order systems theory hold true, the answers to these questions will offer clues as to the durability of change induced through external stimuli in the context of Polish higher education.

To investigate the interaction between external stimuli for change and identity patterns in major types of Polish HEIs, this study sought to uncover the "rationalized myths" (Meyer and Rowan, 1977; Schriewer, 2009) of the university held by key players in the system, both policymakers and academic leaders. Rationalized myths are accepted narratives "depicting various formal structures as rational means to the attainment of desirable ends" (Meyer and Rowan, 1977, p. 345). In the context of this study, this notion, derived from institutional theory, served as a conceptual bridge towards the operationalization of organizational "DNA" - an experimental key to try to unlock the organizational pattern of identity.

Rationalized myths are not mythical in the sense of being false, but in the sense of presenting a proscribed construction of the world and conditioning behavior. It was assumed in this study that rationalized myths constitute the singular "genes" of an organization's autopoietic "DNA". Support for the use of this particular concept came in part from the neo-institutional insight that rationalized myths play a particularly significant role in organizations that experience high levels of environmental uncertainty and an ongoing need for social legitimacy such as current institutions of higher education. It is hypothesized that policy actors and academic leaders in different types of institutions 
function in diverse social systems, and they will therefore communicate and enact different structures for attaining different desired ends.

\section{An authoritative blueprint for governance reform}

In recent years, the "rationalized myth" prevalent in European policymaking conceptualizes HEIs as a quasi-markets, governed by mechanisms of managed competition overseen by the state (Agasisti and Catalano, 2006). It emerged in response to calls for higher education to become more efficient and responsive to taxpayers' concerns, translated into efforts by European governments to align institutions of higher learning with the priorities of social and economic development. Market-oriented policies were seen as the formal structures and rational means for reform (Bok, 2009). European governments have opted to grant HEIs more autonomy in return for greater efficiency and accountability.

The ideological grounding of the "rationalized myth" embedded in the new policy template was found in the principles of New Public Management, in which market-oriented management is seen as a means to increase public sector efficiency. Market-oriented trends in public management were set against what scholars refer to as the emergence of a new "regulatory state," which in Europe represented a fundamental change from state-bureaucratic 'welfareism' (King, 2007). Greater institutional autonomy is combined with competitive funding mechanisms and performance measurement (Gornitzka et al., 2007; Maassen and Olsen, 2007; Trakman, 2008). The new, post-bureaucratic forms of governance retain diverse conceptions of the mission of higher education, and have their roots in diverse institutional traditions. Nevertheless, there are common features that allow for the recognition of the new model as a "common policy template" (Capano and Regini, 2014). These features include:

the separation of operations from policy-making within government departments, the construction of a formal distinction between purchasers (government) and providers (market), and the establishment of independent agencies at arm's length from ministers to retain influence over the market on behalf of the public interest (King, 2007, p. 413).

Some scholars have used the term "New Managerialism" (Braun and Merrien, 1999) as description of a model with redefined links between universities, markets and the state. The new blueprint is perhaps more accurately typified as a post-bureaucratic hybrid of market and state coordination, in which the state acts as an arbiter for the market (Gornitzka and Maassen, 2000). Authors of a cross-country study of governance trends concluded that in the new framework, "It is as if the governments want to make sure that the universities and colleges use the larger autonomy in such a way that the outcomes the governments expect of enlarging the autonomy are indeed achieved." (Gornitzka and Maassen, 2000, p. 284).

The "common policy template" (Capano and Regini, 2014, p. 73) was reinforced and legitimated by the European Union through its Lisbon Agenda, launched in 2000 with a strong focus on knowledge as the European economic engine. Policies such as concentrating power in fewer hands, strengthening HEIs' ties to the socioeconomic environment, and funding based on performance became an authoritative blueprint for reform. Since then, European higher education systems have become increasingly similar - a phenomenon studied and theorized extensively by political scientists (theory of convergence - see e.g. Heinze and Knill, 2008; Dobbins and Knill, 2009; Dobbins, 2011; Dobbins (2017)) and organizational sociologists of the neo-institutionalist school (institutional isomorphism - see e.g. Zha, 2009; or world systems - see e.g. Schriewer, 2009). Convergence in higher education is an aspect of larger processes of global isomorphism and standardization in education (Schriewer, 2009).

\section{Polish reforms of science and higher education}

The Western European shift towards "common policy template" was a significant feature of the policy context of Polish higher education. Marek Kwiek, a leading higher education scholar in Poland, notes that for the first time since 1989,

"the state is becoming a stakeholder with its own, distinct say in higher education. And for the first time, a say of the state as a stakeholder is different from a say of (the part of) the academic community" (Kwiek, 2012, p. 167)

The ground-breaking reforms of science and higher education passed in 2009-2011 during the tenure of Barbara Kudrycka as Minister of Science and Higher Education, as well as the more recent "Law 2.0" discussed further in the paper, share a great many features consistent with the European template. The reforms passed in 2010/2011 assumed two primary goals: 1) intensified creation of new knowledge, operationalized with quantitative indicators as high-impact publication, and 2) high quality education, operationalized through a National Qualifications Framework (NQF) - an integrated referencing system for qualifications that uses learning outcomes as a major point of reference across all educational sectors. The NQF was based on the European Qualifications Framework (EQF) - an EU-wide initiative to make qualifications more readable and transferable across member countries.

In the realm of science, policy-making was separated from the operations of funding science by creating two independent funding agencies for basic and applied research - National Science Centre (Narodowe Centrum Nauki) and the National Centre for Research and Development (Narodowe Centrum Badań i Rozwoju). The statutory research subsidy was all but eliminated, and the agencies now disburse funds exclusively on a competitive basis. The reform also created an advisory body, Committee for the Evaluation of Scientific Units (Komisja Ewaluacji Jednostek Naukowych), that compiles annual rankings based on research performance, with financial support from the state depending on the grade received - a mechanism maintained and strengthened in the next wave of reforms passed in 2018. Since the first wave of reforms, academic units ${ }^{1}$ have been evaluated using externally defined indicators, with criteria weighed towards faculty publication in English-language journals with impact factor ratings (Kulczycki, 2017).

In the realm of higher education, HEIs are mandated to follow the National Qualifications Framework and to meet standards of evaluation, while their autonomy to design programs of study was increased. In $2010 / 2011$, the powers of the central university administration were expanded to include the creation, reorganization and closing of academic units. The reform also gave universities two options for governance selection, allowing them to choose between the current traditional model and what it calls a "managerial" model. In the managerial model, the rector was to be selected in an open search and then had the freedom to conduct open searches for deans and vice-rectors (except the vice-rector for academic affairs, the equivalent of the Provost in the U.S. system), and make his own selections. The reform also maintained the requirement set in place in the 1997 Law on Vocational Higher Education that Boards of Trustees (Konwent) exist at Vocational Higher Education Institutions (Wyższe Szkoły Zawodowe); other institutions were encouraged but not required to appoint such boards (Poland, 2010).

A comprehensive reform passed in 2018 under Minister Jaroslaw Gowin went a step further in pursuing the logic of more autonomy in return for greater accountability to public interest in social and

\footnotetext{
${ }^{1}$ The 2010 law on the financing of science defined an academic unit as an institution continuously conducting research and/or development, which includes basic organizational units of HEIs as specified by their statutes, units of the Polish Academy of Sciences, research institutes, the Polish Academy of Skills, and other legally registered research organizations.
} 
Table 1

Government Sample Composition $(\mathrm{n}=12)$.

\begin{tabular}{|c|c|c|c|c|}
\hline & Ministry of Science and Higher Education & Reform architects & External experts & Political advocates \\
\hline Participants & 3 & 3 & 2 & 4 \\
\hline
\end{tabular}

Table 2

HEI Sample Composition $(n=20)$.

\begin{tabular}{|c|c|c|c|c|}
\hline & President, Vice-President or former President & Senior Administrator & Member of Governance Body & Informal Leader \\
\hline Flagship & 2 & 1 & 2 & 1 \\
\hline Technology & 1 & 2 & 2 & 1 \\
\hline Specialized & 1 & 1 & 2 & 1 \\
\hline Vocational & 0 & 1 & 1 & 1 \\
\hline Total & 4 & 5 & 7 & 4 \\
\hline
\end{tabular}

economic development, as defined by the state. The Committee for the Evaluation of Scientific Units was renamed the Committee for the Evaluation of Science (Komisja Ewaluacji Nauki), and it is now to evaluate research in a given discipline rather than in a specific academic unit of a university - yet it is still on the basis of externally defined indicators favoring internationally visible publications (Poland, 2018). Two of the most significant changes take the system further in the direction of the "common European policy template." The new law expands the powers of the rector to include setting the organizational framework determining the institution's structure (previously a prerogative of collegial bodies), and - most controversially - introduces mandatory Boards of Trustees at all public HEIs. The composition of these boards was contested - the initial project assumed the majority of the Board should come from outside the institution, but after protests from the academic community, it was changed in its final form to require external representation to constitute at least $50 \%$ of the Board. The functions of the Board in the law are also less extensive than in the initial project - the Board is to give opinions on the institution's statute, strategy, and reports on the implementation of the strategy; to monitor finances and management, and propose candidates for the post of Rector upon their evaluation by the Senate.

What has remained unknown to date is how reforms moving the system in the direction of an instrumental vision of the university intersected with the patterns of identity at different types of institutions, ranging from a flagship research university to a higher vocational school. Did they occasion a conflict of "fundamental values," as hypothesized by Kwiek (2015, p. 87)? Were pressures to improve external relevance seen as consistent or inconsistent with the different identity patterns of different types of institutions? Is there evidence for change in any of the organizational identity patterns as a result of reform? This research, conducted between the two waves of reforms, is an attempt to answer these questions.

\section{Methods and design}

The investigation employed a qualitative methodology to explore the ideas of policymakers on the one hand, and academic leaders on the other.

The author interviewed two groups of respondents: 1) Twelve architects of the 2011-2012 reforms and experts involved in the legislative process that led to its passage; 2) Twenty academic leaders of four public HEIs, representing the four main institutional types.

A.) Flagship HEI: one of only two HEIs in Poland ranked in the top 400 universities in the world, considered one of Poland's two flagship universities.

B.) Technical HEI: one of the 31 public universities of technology (politechniki) in Poland, with long-standing traditions of cooperating with industry.
C.) Specialized HEI: one of the so-called uniwersytety przymiotnikowe - universities that grew out of specialized institutions, established or re-organized after 1946.

D.) Vocational HEI: one of 36 State Higher Vocational Schools, the youngest type of public HEI in Poland, established since 1997.

At each HEI, interviews were conducted with the rector, one vicerector or former rector, one senior administrator, two members of a governance body, and one informal leader - since, as the work of Sztompka (1993) and others indicates that in a post-communist social system, those with the greatest power are often not those who occupy powerful positions. The composition of both samples is summarized below (Tables 1 and 2).

The primary method employed in this study was the elite interview, and to ensure the validity of the data in the Polish context, the interviews took place during the researcher's extended stay in the country. The researcher became immersed in the social world of study participants for one year (2013-2014), using the opportunity of a visiting appointment with an academic unit that trains leaders and managers for the public sector, including higher education. Personal connections through colleagues in the unit brought with them invitations to academic functions and closed events sponsored by organizations such as the Foundation of Polish Rectors and the Conference of Rectors of Academic Schools. Thus, the researcher was either known to respondents prior to the interview, or received recommendation by a member of a common private network - a rare feature in research usually conducted in the region. It has been demonstrated that in postcommunist societies, people commonly experience a "split in social consciousness" (Sztompka, 1993, p. 246) along the public-private divide, with communication styles differing considerably depending on whether the interlocutor is perceived as a member of the public or private sphere. The researcher's positionality as an outsider connected to private networks and mastery of the Polish language bolstered the validity of the findings in ways rarely achievable in similar studies in the region.

Interviews were conducted, transcribed and analyzed for recurring themes in the original language. Content analysis was conducted in MAXQDA to compare the two groups for markers of identity operationalized as "rationalized myths" of the university. The first wave of coding employed Clark's (1986) classic triangle of coordination as the initial source of coding categories (Shaw, 2018); however, in-vivo codes emerging from language used by the participants themselves suggested a coding structure built upon the distinction between institutional and instrumental logics. The detailed operationalization of the two "rationalized myths" in the analysis of the interviews is presented in Appendix A. Interview segments were coded for the "rationalized myth" they approximated, and for the evaluative stance of the speaker, so that both positive statements and criticisms could be analyzed.

In consistency with a theoretical framework employing systems 
theory, this study was rooted in an interpretive approach, assuming that people ascribe different meanings to the world around them, and the meanings they construct constitute an essential element of social reality (Menzel, 1978; Schwandt, 2000). Regardless of their ontological or epistemological merit, subjects' meanings and interpretations have a real impact on the world they inhabit - or as Thomas and Znaniecki (1927) noted, "if men perceive situations as real, they are real in their consequences" (p. 81). The researcher's aim was to observe and interpret reality in terms of what it means to the people included in the study, with the goal of producing a representation the subjects themselves would recognize (Geertz, 1973).

\section{A conflict of rationalized myths: instrumental vs. institutional visions of the university}

The findings of this study lend credence to Kwiek's (2015) hypothesis as to the existence of a conflict of values between policy actors and academic leaders regarding the aims of the university and its proper relations with the state. ${ }^{2}$

Policymakers unequivocally assume the "desirable end" of higher education is the development of the economy and society through the "rational means" (Meyer and Rowan, 1977, p. 345) of fair competition, embracing a clearly instrumental logic (Fig. B1 in Appendix B). The desirable ends and rational means assumed by academic leaders are less uniform, yet to the majority of respondents in this group, the university is primarily an institution engaging in the disinterested pursuit of truth by means of mutual, trust-based accountability (Fig. B2 in Appendix B). The strength of this pattern of identity was greatest at Flagship and Specialized universities, followed closely by Vocational HEI; the only institutional type where the reforms were not seen as perturbations to the proper mission of the university was Technical University. A visual representation of both positive and negative statements by respondents is available in Appendix B.

Significantly, both groups perceived cracks in their "rational means" that threaten the attainment of the respective "desirable ends." As further, the existence of these cracks results from a problematic intersection of the two "rationalized myths." Using the language of systems theory, compensations aimed at restoring the system's ability to selfperpetuate threaten the realization of its native pattern of identity without delivering the outcomes desired by their source.

Detailed findings follow in the subsequent two sections, with the majority of the discussion devoted to the academic sample.

\subsection{Instrumental Myth: "if the state pays for something, it expects specific} results"

Polish policymakers clearly embrace the instrumental view of the higher education sector as a tool of state policy to achieve economic growth and social development through mechanisms of fair competition. Competition was a word used 41 times in the 12 interviews with policy actors, compared with 13 times in the 21 academic leader interviews.

In the views of these respondents, higher education is too important to be left to the whims of a very imperfect educational market. Multiple respondents noted that a truly free market is not possible unless "consumers" are the ones paying for a "service" and assessing its value - and most students at public universities in Poland do not pay for their education. In an imperfect market, where it is the state that pays for public higher education, it is also the state that takes up the role of advocate to the consumer:

\footnotetext{
${ }^{2}$ Since this study is not representative of all Polish academic institutions, when speaking in the following section of "policy actors" and "academic leaders", it should be clear that the author is referring to the respondents in this study.
}

\section{...if the state pays for something, it expects specific results. (108:34)}

In the non-ideal situation in which the majority of public university funding comes directly from the state, it is up to the state to make sure public money is being spent well; and what "well" means is determined by the state.

According to respondents in the policymaking community, it is up to the state to evaluate the outputs of higher education and to incentivize those perceived as strategic for national development. In a manner reflective of the instrumental logic and the European policy template, policymakers thought that the state must skew the educational market in favor of those who will provide the best services with the greatest public benefit. Not one person among those interviewed believed "the invisible hand of the market" would ensure the best private or public returns, at least not in the current legal, economic and cultural environment. It is presently too easy to deceive potential students, the costs to the public are too high, and the effects take too long to be seen. Without some control from the state, too many people would want bogus degrees, and too many universities would be willing to provide them. The educational market is also too obscure and too imperfect to allow for truly informed choice, so the state that pays for so much of public higher education must also act as the arbiter of what kind of education serves public interest. The view of the state as an ally and protector of public good in higher education is illustrated well in the following excerpt:

The way I see it, progressive forces in higher education should notice incentives from the state, and if they are intelligent, they will see the state as their ally. (108:38)

While policymakers shared the view of the state as the one who establishes the playing field, who pays and demands - they differed in their ideas about the extent of what the state can and should demand. Some thought that the government should merely provide fair rules, create transparent systems of information, and allow the market to do the rest. The market, for example, should play a key role in evaluating the preparation of graduates, even those at the doctoral level:

I like what you have in the States, that a young person graduates or gets a doctorate, and it's the external world that evaluates him. (110:40)

Others favored a more robust state involvement in controlling the educational process, especially as far as setting benchmarks for quality and preventing pathologies.

What does it look like in practice for the state to act as an arbiter of public interest? In the absence of better benchmarks, the state has attempted to do this by requiring minimal levels of education for academic staff in state-accredited programs. Undergraduate study programs were mandated to employ at least three academic staff with the Doctor Habilitatus (Doktor Habilitowany) degree, and at least six with doctorates in the required academic field. In practical fields, up to one Doctor Habilitatus could be replaced by two Doctors, and up to two Doctors could be replaced by two faculty with Master's degree in that field. ${ }^{3}$ Each academic staff could only be counted towards the minimum requirement at one institution. While recognized as imperfect, this mechanism was cited as an example of the state protecting the interests of the public - a claim disputed by academic leaders cited in the following section.

Full-time employees of the Ministry unaffiliated with other institutions spoke most distinctly about the role of the state being merely supervisory, limited to financing and accreditation. They claimed that in the system of higher education as a whole, they hold much less influence than the academic community itself:

\footnotetext{
${ }^{3}$ The law provided exceptions to this rule in select disciplines that have been in existence for some time and were able to make a case for differential treatment.
} 
The role of the ministry is limited to supervision, just supervision. Control of the fulfillment of their tasks. So the ball is $\mathbf{1 0 0 \%}$ in the HEIs' court. (106:34, emphasis added)

As noted further, however, a merely supervisory role of the Ministry appears to be an aspirational ideal. Policymakers clearly believe they should play a very limited role, but the role they actually play is quite substantial. It has been noted that during the tenure of Barbara Kudrycka (2007-2013), whose senior employees were interviewed for this study, the role of the Ministry in steering higher education became more assertive than at any point since the post-socialist transition (Kwiek, 2012). To mention just a few examples, the Ministry plays an assertive role in determining the criteria for the research subsidy and for state accreditation, setting strategic funding priorities for programs deemed crucial for national development, and selecting members in all major bodies such as the Committee for the Evaluation of Academic Units, the Polish Accreditation Commission, and the Main Council for Higher Education. Therefore, the ball being in HEIs court can either be interpreted either as an aspirational ideal, or as a defense of the increasing exercise of state muscle in higher education.

Nevertheless, the reforms of 2010-2011 certainly did aim, at least in theory, to give HEIs the freedom to shape their research agendas and study programs, with indirect control at the level of evaluating the quality of internal evaluation measures and final outputs:

Institutions have received more autonomy... They have more freedom, they have more scope in their affairs, and a different mechanism was set up, namely external quality assurance, which only becomes necessary in this context where you don't have this direct control. However, it is exactly in this context that some kind of external oversight and involvement of society at large makes sense. So basically the two sides of the coin being autonomy and accountability. (107:13)

The trend to increase accountability and incentivize externally defined quality is most evident in how the Polish government evaluates and funds research. It was summarized bluntly by a member of the Committee for the Evaluation of Academic Units who said:

Do as you please. Yet it's not quite do as you please - do as you please and at the end of the year come show me your points. (102:131)

The "points" mentioned by the respondent refer to a national system for the evaluation of academic units. The reforms of 2010-2011 introduced a ranking of departments and centers by the scientific output of their employees. Using parametric criteria such as the Impact Factor, the Committee for the Evaluation of Scientific Units assigned each unit one of four categories, determining the amount of a statutory research subsidy received by that unit for the following four years. The evaluation was based on a point-based ranking of scientific publications announced annually by the Ministry of Science and Higher Education. ${ }^{4}$ The logic of the mechanism is to incentivize deans and other unit directors to recruit and retain highly productive academic staff whose achievements will translate into increased funds (108). Since all other funding for research in Poland is disbursed on a competitive basis by independent agencies that also use the ministerial ranking as a guideline, ${ }^{5}$ nearly all research funds are supposed to be distributed according

\footnotetext{
${ }^{4}$ The ranking consists of three parts: A) Journals that have an assigned Impact Factor in the Thomson Reuters Journal Citation Reports (JCR) (15-50 points); B) Journals that do not have an Impact Factor (1-10 points), and C) the European Reference for the Humanities (10-14 points).

${ }^{5}$ Basic research is funded by Narodowe Centrum Nauki (National Science Centre - NCN); while applied research is funded by a separate agency, Narodowe Centrum Badań i Rozwoju (National Centre for Research and Development - NCBiR).
}

to externally defined and performance-based criteria. This represents a radical departure from past practices, when statutory research funds were not tied to performance, and became distributed through academic hierarchies. In the view of most of the policymakers, steering through objective performance-based criteria eliminates cronyism in the distribution of taxpayers' investment and sets the system of higher education and science on course towards greater public benefit.

Among respondents from the policy arena, there was one significant voice of dissent with regard to the merits of performance-based criteria. A respected academic affiliated with one of the country's top universities who served for a term at the Ministry of Science and Higher Education saw the logic of setting goals and demanding results as detrimental to genuine creativity and development:

Autonomy of HEIs is a guarantor of the academic freedom of thought, of creativity. If you just give a task and finance it and hold people accountable to it, you put a hamper on development. (103:52)

In this view, the university is a forge of new ideas foundational for the process of innovation, and many such ideas would not appear if everything was measured and accounted for. Instrumental and institutional roles of higher education go hand in hand, and recent reforms go too far in attempting to measure the unmeasurable.

Over all, policymakers spoke of three ways in which the state is attempting to incentivize desired outcomes in the provision of higher education.

i Mandating the inclusion of student evaluations of teaching in mandatory evaluations of academic staff;

ii Mandating universities to collect tracking data on their graduates, and from 2015 - publishing longitudinal data on graduates 'earnings based on the national higher education database combined with anonymized data from the Social Security Administration (Polish Graduate Tracking System, 2018);

iii Implementing the Polish Qualifications Framework (PQF), based of the European Qualifications Framework - consisting of eight qualification levels, with learning outcomes described in the three categories of knowledge, skills and social competence.

Since the reforms in 2010-2011, in order to be accredited, higher education programs must formulate their curricula in terms of learning outcomes described in the Framework (Educational Research Institute, 2013). In the past, the Ministry had maintained a set list of 118 study programs and their required components. Now HEIs have greater autonomy in shaping their study programs as they please, provided that the learning outcomes align with the PQF. In the accreditation process, the Polish Accreditation Commission verifies whether the validation of learning outcomes is consistent with programs' stated aims. As becomes evident in the next section, all three mechanisms are seen as quite problematic by academic leaders, and the root of the opposition goes back to a fundamental disagreement about the nature of the university.

In summary, the state's instrumental view of higher education evident in the interviews as well as actual policies implies incentivizing outcomes perceived as strategic - whether by increasing competition in research, making sure HEIs evaluate what they say they want to accomplish, or by providing the public with reliable information on their outcomes. Cracks in this view tend to be visible to those immersed in the organizational setting of a traditional flagship university. This "rationalized myth" is problematized by the realities of an imperfect educational market and a perceived need for the state to mandate and legislate more than what would be considered ideal by respondents.

\subsection{Institutional Myth: "protected from the rationality of the market"}

For the majority academic leaders included in this study, higher education is not primarily an instrument of development, but an 
institution engaging in the disinterested pursuit of truth and the formation of broadly educated citizens. In the context of a knowledgebased economy, the benefits it provides for individuals and economies are seen as significant and taken very seriously by the respondents - yet those are mere side effects of a more essential mission of higher education. A professor who had spent years training university executives summarized this notion when he said:

The university has two tasks; on the one hand, to hold up tradition, which is the identity of a given community, and on the other hand, to speak out against that which is harmful to this community... The role of the university is to proclaim truth and speak against error. This is the best definition of the university mission. (206:28; emphasis added)

\section{Another respondent said:}

The whole concept of the university is about disinterestedness. If the university is subjected either to business or to politics, then it is just a service provider. (217:43; emphasis added)

The aim of higher education is to push the boundaries of knowledge and to provide students with a holistic education, in which employment skills are not the main focus. Such sentiments were expressed most forcefully at Flagship University.

Ideals of pursuing and teaching truth were seen by many as being undermined by the recent policy shifts aiming to make higher education an engine of economic growth. The notable exception was the University of Technology, where complaints regarding the government's policies had more to do with the tightening grip of bureaucracy associated with increased accountability for outcomes - a concern expressed by policymakers as well. At the same time, the goal of aligning higher education and science with the market was seen as positive interestingly, not so at Vocational HEI, established for the purpose of practical training. The University of Technology was the only HEI at which the goals of pursuing truth and providing high returns to higher education were seen as complementary.

At all institutional types, less respect was accorded to practical training programs that prepare graduates for specific jobs. The richest and most heated discussion surrounding HEIs' mission centered on a widespread sentiment that the aim of a HEI is to give students a broad education, not narrow job training. Leaders of Flagship University and Specialized University in particular expressed strong opposition to the idea that the role of the university is just to provide targeted training for the workforce:

If the employer complains that we do not have a study program that will prepare his employee for a specific workplace, we just don't have that. That's not what universities are for. (201:38, emphasis added)

Arguments to the same effect are often heard in the Polish media, most famously in the inaugural speech by the new rector of Warsaw University in October 2013. The youngest rector in recent history said:

The university is not a company, and accounting is not the queen of the sciences. HEIs are not responsible for the condition of the Polish economy... I have no doubts that various vocational schools are necessary. Ignoring technical knowledge would be a mistake, but we are pouring out the baby with the bath water. Why should practical qualifications be Poland's trademark? Will welders solve the current social and economic problems of the country? Will Polish seamstresses beat those from Bangladesh? (Gazeta Wyborcza, 2013-1001).

The view of the university as a temple of knowledge was most pronounced at Flagship HEI and Specialized HEI, where such a view coincided with an overwhelmingly negative assessment of the massification of the higher education system. Yet not only here but at all four types of institutions academic leaders wished for the return of the days when there were few students, small seminars, and opportunities building a master-student relationship. They recognized that not all HEIs need to be universities in the traditional sense, but none of them wanted to be anything else. Much like the rector of Warsaw University, they claimed various vocational schools are necessary - as long as it is someone else playing that role, not their institution.

The majority of academic leaders, with the notable exception of Technical University, described the realities of massification and mandates to make education practically relevant in terms suggesting that they were undesirable perturbations contrary to HEIs 'proper mission. Interestingly, such sentiments also prevailed at Specialized and Vocational HEI - institutions whose official mission statements refer to the development of practical competencies. Representatives of both of these institutions stated that if they could, they would eliminate the adjectives attached to their names and assume the same status as "normal," traditional universities. Respondents at Flagship University complained of the devaluing of the term "university. "Interestingly, the same criticism was reiterated at Specialized University, which itself called itself a "university "only within the last twenty years.

The resilience of the organizational pattern built around the agenda of pursuing knowledge and providing a liberal education appears to be fueled by two principal dynamics. First, the majority of HEIs were built on the organizational blueprint of traditional universities, which is also where they drew from for their staff:

If you look at the staff of practical HEIs, let's say the State Vocational HEIs and private HEIs, their staff came from large public universities... These HEIs usually do not have the rights to grant Ph.D. or Habilitatus degrees, or at the most they have the rights to grant Ph.D.s in a few disciplines. So the staff comes from universities and grows up within their patterns. (213:46)

The identity of the university as a self-governing community in search of truth is not a matter of culture alone. Reforms to the system of higher education since the 1990s were designed by experts from traditional universities, who entrenched their logic in legislation and funding policies that apply equally to a flagship university and a vocational institution. Even in the 2011 reform, greater autonomy to open new educational programs without ministry approval was granted only to institutions and units with the right to grant Habilitatus degrees. The funding formula also continues to favor HEIs with academic profiles:

There is power in granting academic degrees and titles... It gives greater autonomy, and higher subsidies for teaching. The prestige is higher because we can educate our own staff, and staff for others. It matters in rankings and financing algorithms. (218:56)

While critical of the government's efforts, academic leaders recognized and accepted that to realize their goals in the present age, HEIs must play by the rules of the market. The market is where the resources are, so it has to be reckoned with - but everywhere except the University of Technology, it was seen as a reality that must be lived with and even exploited for one's own ends; but not given in to as far as mission is concerned.

As a result of market forces, applied research, which used to be held in contempt, is now more respected for the money it brings in, especially at the University of Technology:

No applied science, until recently these things were treated as a worse kind of science. It's not that way anymore. (207:31)

Yet even at this university, which has the strongest links to industry, some disagreed on the ultimate value of applied research: 
What is most highly valued is bringing in grants, large grants from industry, which can certainly be of benefit to the country. But is this beneficial for furthering knowledge? I don't think so. (214:9)

Even at this institution, grants for basic science from the National Science Center were seen as more prestigious than the applied grants from the National Center for Research and Development.

What academic leaders from all institutional types had in common was a view that the striving of the Ministry to steer HEIs towards greater socioeconomic relevance by means of mandates and output measures is achieving the opposite of what was intended - these "rational" means are not achieving the results desired by the Ministry. The critique of the government's current approach was summarized by a dean at Flagship University, who said:

An economy should be innovative, but I don't know if you can impose the obligation to innovate from above, with a decree of the dean, the rector, or the minister. (224:19, emphasis added)

The sentiment was echoed to various degrees at all types of institutions that in its efforts to mandate productivity, the government has stripped HEIs of the freedom they would need to innovate in genuine ways - a concern shared by policymakers. Academics are free to research what they want, provided that they can obtain funds from institutions that disburse them according to what is deemed strategic to the country. They can teach what they want, as long as it aligns with the PQF. While recent laws may represent an ideological shift towards greater autonomy and accountability, the full body of regulations prevents the greater autonomy from becoming a felt reality.

Four respondents described the law using the same word - a "corset" $(210,213,214,217)$. The feeling of being bound was especially common among deans and those at the middle level of HEI governance structures:

\section{I am in a corset of regulations. I can't do anything. (217:51)}

Leaders of academic units, with the notable exception of Technical HEI, said they are hemmed in by the law and too overwhelmed by the burdens of bureaucracy to lead in a strategic or competent way. Respondents provided telling examples of how their ability to design marketable study programs in accordance with the Polish Qualifications Framework is restricted by requirements set out by the law to protect educational quality as operationalized by the state.

For example, at Vocational HEI, legal restrictions prevented the opening of publically subsidized programs in Information Technology, Materials Engineering and Agrotourism - fields that represent growing sectors of the economy. The application to open a program in Information Technology was denied because too many of the Ph.D. holders listed for the minimum staffing requirement received their degrees in disciplines other than computer science. An administrator at Vocational HEI explained that holders of doctoral degrees in Information Technology are very hard to find because their demand exceeds supply, and they are able to make three or four times more outside academia. The same problem was confirmed by a dean in the hard sciences at Technical University, who said he had seven unfilled positions at the time of the interview for which he could not find candidates (216). In the case of Vocational HEI, if the law was not as restrictive, it would have been possible to fill open positions with holders of Master's degrees, and such instructors would have been preferred. As a few respondents noted, holders of advanced degrees trained at public research universities transplant their preference for theory over practice to HEIs that exist to train students in practical fields (213:46). Yet for the sake of meeting the minimum staffing requirement, the administrators at Vocational HEI had to resort to finding Ph.D. holders in other disciplines who used information technology, such as Quantum Physics - and still, their application was denied (220).

Vocational HEI was also denied applications to open programs in Materials Engineering and Agrotourism. The reason was that they did not have the proper laboratories and infrastructure on campus, although they had signed agreements with commercial firms and a partnering university to make such infrastructure available until the HEI can develop its own. The reason for the denial was a legal provision that requires HEIs to demonstrate that they have the necessary classroom space and equipment on campus (221). At present, Vocational HEI offers degrees in academic fields, such as political science, philology, management, and pedagogy. In conclusion, one administrator said bluntly, "we are aware that we are producing unemployed people "(221:32). Leaders of this university realize that what they offer to students is inconsistent with what they say in their mission statement, or with what the students come for - but they feel they do not have the agency to change it.

Representatives of the government had explained the increasing regulation results from three imperatives: 1) Eliminating pathologies; 2) Fulfilling the duties of European harmonization; and 3) Promoting high quality of teaching and research. The official who listed these imperatives also admitted that with the exception of the new grant funding mechanisms, the policy instruments are almost exclusively mandates:

I would say it was a repressive approach - too much moonlighting, so let's forbid moonlighting. Too much nepotism, so let's forbid nepotism... (108:6)

According to academic leaders, the result is that the measures intended to eliminate pathologies often produce further pathologies (217, 222). For example, since it is no longer legal to have two full-time jobs, and academic positions still pay below the national mean, academics take on independent contracts that give them less money than before, engendering the necessity to take on even more jobs to stay in the middle class. Tightening restrictions in the areas of public finance, many of which get interpreted differently by different officials, discourage academic leaders from applying for external funds in fear of audit and looming penalties for non-compliance. The legal "corset" meant to protect quality makes both officials and academic leaders inflexible, fueling their reluctance to act in entrepreneurial ways. Even those academics who affirmed the ideas behind the regulations thought that their intended aims were being degenerated by fear:

The idea of the system in Poland is good, but out of fear, officials demand more than necessary. The same goes for applications to the European Union - the criteria are milder there, and here they are made harsher out of fear. (219:21)

In the view of academic leaders, HEIs are no longer autonomous communities of scholars, or if they are, they remain so by acting on the edge of the law. At the same time, HEIs are also not the instruments of national development envisioned by the government. They are something in between, and their uncertain position achieves neither of the two visions.

Academic deans in particular noted that even though the government claims it wants to evaluate outcomes, they in fact do not trust universities and therefore control minute elements of the educational and research processes, leaving little room for strategic leadership at the level of individual HEIs. One particular statement by a dean at the University of Technology stands out as a stark judgment of the emerging system, all the more striking because it was uttered by someone who sympathized with the reformers' aims more than most respondents:

It is just like during communism. The constitution said that 
everyone is free, there is freedom of association, freedom of speech, except it must be regulated. We also have full autonomy, but it must be regulated. The number of regulations sent non stop to HEIs is such as we did not absolutely have under the previous regime... On the one hand, the state claims that they give us complete autonomy, but it is just an appearance. They give us autonomy when it comes to the content, but not when it comes to the form - but the form determines what you can put in it. (214:61-62, emphasis added)

If academic leaders see freedom as a critical condition for the proper functioning of higher education, and criticize the government so heavily for its regulatory efforts, what is their view of the proper form of accountability? Contrary to what the government officials may think, what is central to the mission of the university cannot be measured:

a university cannot be made into a firm because apart from its commercial tasks, it has one overarching task - to educate people in a way that cannot be measured. (219:59)

The mechanisms of evaluation and accountability of which academic leaders spoke favorably are informal and unwritten, allowing for flexibility and enabling free pursuit of knowledge in community with students. The notion of a quantifiable measure of quality in the education of students was seen as particularly utopian - an insight actually shared by policymakers. While a few may have dreamed of including the employment rates of graduates in the funding algorithm $(104,108$, 110,111 ), nobody thought this would be viable - because it would obscure the educational value added and penalize HEIs that target underprepared students. Since the quality of teaching is not as easily reducible to quantitative indicators as the quality of research, it is controlled and regulated on paper - but not rewarded in real life.

To the academic leaders included in this study, the ideal form of accountability is a matter of organizational culture, not an Excel spreadsheet of standardized points. The only kind of accountability that does not stifle creativity is one where academics evaluate each other on an individualized basis. This kind of evaluation continues to function despite the efforts of the government of objectify and standardize it:

There must be a system of verification, and it actually does exist in the academic community as in every community - the hierarchy is known of who is good and who is worse. It is unwritten and these points don't change it. (219:33)

Evaluation of creative academic endeavors, in teaching as well as research, is too complex to be reduced to a set of externally defined indicators. An example brought up in a variety of contexts was that of Immanuel Kant - one of the most significant figures in Western philosophy who would have been fired by the current point-based criteria, since he produced only one small book in ten years. A good system of academic accountability is one that supports people like Kant instead of eliminating them for the sake of meeting performance standards.

While there was apparent agreement that the ideal is mutual accountability of academics accompanied by social trust, a minority of respondents questioned whether this ideal could ever be realized in Poland due to a deficit of trust $(203,205,214,217,222)$. These voices are unsurprising given the central role of trust in the idealized system proposed in a country with one of the lowest levels of social trust in Europe (European Social Survey, 2018). The dilemma was captured by one person who said:

For science to function normally, you need trust. Trust is at a deficit in Polish science. (222:16)

In five rich interviews, favorable discussions of the ideal of trustbased accountability were accompanied by statements like, "of course, it's a utopia" (217), "it's a type of academic culture that we won't ever have here" (214), or "it's practically impossible "(203). A few others described what they would hope for universities to be, and then go on to say why it will not work. The culture of Polish academia as painted by these five respondents is one in which personal and institutional goals are often achieved by evading formal rules and officially stated processes. Having complained about increasing regulation and expressed nostalgia for trust-based accountability, some of the respondents went on to say things such as this:

It is not working in Poland at all. That is my impression. But it is not the government's fault, the culture is what is to blame. (214:11)

For twenty years after the transformation, the academic community was governed by democratic principles, with freedom to set its own priorities and to regulate itself. Due to mental and social habits that preclude trust, attempts at trust-based accountability produced a system of rewards that actually rewarded those who performed less well. Given the abuses of trust-based accountability, it is no wonder to some respondents that the Ministry took a more decisive stance. While they may disagree with the solutions, their impetus is well-understood:

For twenty years the academic community has shown that it is not able to govern itself, and it cannot set its own priorities... Although I disagree with the Ministry, I understand them. If you are unable to govern yourselves, you will have a hegemon. (222:11; emphasis added)

Elements of the culture cited as contrary to the basic prerequisites of trust-based accountability were described in the following way:

What we have here is in some sense an outcome of the mentality that a Pole will finagle, a Pole will find a way around. Perhaps this is a harsh judgment, and it is unfortunate... Poles are excellent at going around various regulations, there are influential people with the old mentality, and the new generation is similar. (219:25,57; emphasis added)

The original word used by the respondent is the term" kombinować," which is best rendered as "to finagle" or "to game the system" and connotes manipulating a situation in an attempt to achieve a goal. Unlike the English translation, the Polish word is not pejorative - it suggests finding a way around many obstacles, as illustrated in the following excerpt:

What we have here is a constant finagling, I'm not saying it in a bad sense, but finding a way around everything. (210:8; emphasis added)

In the view of these respondents, "finagling" is a habit that flourished during communism, faded into the background during two decades of self-governance, and was unfortunately reinforced once again by an unrealistically overgrown law that cannot be followed without contradiction. Academic leaders believed that the normal functioning of their HEIs is only possible thanks to loopholes and inconsistencies. This trapped people between options they do not ethically approve of as when they are required by law to hold an open competition for a post expected by a valued doctoral student who has no chance of being considered elsewhere due to nearly all academic hires in Poland being internal to the institution.

Respondents provided numerous examples of evasive behaviors that enabled them to get things done despite laws perceived as restrictive, unrealistic or unfair. For example, a person at Technical HEI who oversaw its impressive rise in rankings and in financial prosperity, said he was only able to lead the university as he did because of a "creative" management of finances, which required making adjustments of dubious legality. A dean at Specialized HEI described how the unfair 
incentivization of English-language publications in the field of Polish Philology could be evaded by means of a mutual publication deal with a colleague just across the border in the Czech Republic to publish in each other's journals what they would have published freely had the regulation not been in place. Examples of this kind were provided freely and openly in about half of all interviews with academic leaders.

The trouble with "finagling", even when it might be a reasonable compensatory response to the invasion of the instrumental "rationalized myth" implemented through overly bureaucratic means, is that it furthers the erosion of trust - both between academics, and in their relation to society. Trust, meanwhile, is at the core of the rationalized myth embraced by academic leaders. Lack of trust translates into more attempts for control, which generates more evasion, and the cycle continues to run its course.

In summary, the logic embraced by the majority of academic leaders is one of social trust in academics to hold up moral standards in pursuit of service to truth, and hold one another accountable while protected from the vagaries of the market - a "rationalized myth" problematized by the realities of low social trust and widespread mechanisms to evade regulation perceived as stifling.

\section{Discussion}

The findings of this study not only lend credence to Kwiek's (2015) hypothesis regarding a conflict of fundamental values between the academic and policy-making communities in Poland, even at the cusp of another round of reforms by a different political party, but driven by the same instrumental myth. More fundamentally, looking through the lens of second-order systems theory, they also paint a picture of a system engaging in "compensations" to external "perturbation" that compromise both the outcomes intended by the source of the perturbation, and the system's own pattern of self-production. In the face of external pressure to produce "desirable ends" defined by the state, the response of a community rooted in a different identity and loyal to a different "rationalized myth" has been to appear compliant towards new demands, but to preserve the fundamental habits characteristic of the university as a disembedded institution.

The government's self-admitted overreliance on bureaucratic mandates appears to be the outcome of an apt recognition of a different pattern of identity, driving a different agenda than the one embraced by the state, and precluding trust in common ends. Academics have had no choice but to adapt to the changing mandates and incentives, but the adaptations should occasion serious pause for the policy community. When the law proscribes open competitions for academic posts, they are announced so as to choose a candidate pre-selected by the academic community according to its own criteria. When criteria for promotion are tied to international publication, faculty arrange a publication deal with colleagues in the Czech Republic. The unfortunate reality is that such adaptive mechanisms undermine the social trust that is at the very foundation of either the institutional or instrumental model of academic work. Even though cycles of perturbation and compensation look to academics more like a return to the communist past than the way of a brighter future, there was no other obvious way to live out the instrumental blueprint.

The roots of this predicament are perhaps best captured using a metaphor. The Polish higher education system in the 1990s resembled the situation of a farmer who needed to plow a field, but did not have a horse. Not having what he needed, the farmer harnessed his dairy cow. The dairy cow did the job, although the trauma from the harness had adverse effects on her health and diminished the quality of her milk. As the farmer's holdings grew and horses were still in short supply, he decided to invest in more cows to plow his fields. Twenty years later, there are horses in the market, but the farmer already has a herd of cows who do not produce good milk because of their harness trauma, but do well enough plowing the fields for the farmer to just barely stay in business.

In the early days after the transformation, the government needed to prepare a workforce for the market economy, but had few institutions or teaching staff specialized in this type of task. What it did have access to were existing universities and other HEIs. The organizational identities and institutional structures of most well-respected institutions were primarily oriented towards an entirely different type of activity than the preparation of a workforce for a market economy - the pursuit of knowledge and the training of broadly educated citizens. The system was rapidly expanded, with a growing number of institutions and academic staff patterned and socialized according to an organizational blueprint that corresponded with goals and myths other than those now placed before both old and new institutions. Twenty years later, the fields of market-relevant education remain crookedly plowed, and the milk of new knowledge is hampered by trauma incurred in the harness of the market. The exceptional case of Technical HEI reinforces the point - the only institution in this study described by none of its leaders as "sick "is one whose root identity is consistent with the myth embraced by the government, and the aim of serving the needs of the economy. Going back to the farming metaphor, the horse that is Technical HEI might suffer when the harness is too tight, but the harness does not deny or restrict its fundamental identity.

In light of the findings of this study, what is the likely impact of Law 2.0, which takes the instrumental logic a step further, offering more autonomy in return for greater accountability while ostensibly reducing the regulatory "harness"? The cornerstone of the reform, which is rewarding institutions that produce quantifiable knowledge shows some promise of bridging the two visions of the university to a greater extent than the previous reforms. Conducting high-quality research at the forefront of existing knowledge lies at the core of what academics see as their institutions' identity, while also being valued from the standpoint of potentially maximizing public returns. The new mechanism of evaluation focusing on selected achievements is already seen as an improvement upon the earlier pressures to produce as many publications as possible, without regard for their intrinsic value to the researcher. Whether the bridge between myths turns out to be viable will depend on the way academic units interpret and operationalize the new criteria for evaluation in passing them down to academic staff.

In addition, two institutions crucial for a promising bridge between the two "rationalized myths "in the sphere of research are the agencies for funding basic and applied science, the National Science Centre (NCN) and the National Centre for Research and Development (NCBiR), which have shown themselves as capable of winning greater legitimacy than their predecessors. Their success in the wake of the recent reform hinges on the perceived validity and transparency of the means employed for evaluating merit in grant proposals, and on the continued commitment on the part of the government to disburse the majority of future funding for scientific research by way of independent institutions rather than through political channels.

Meanwhile, moves by the current government to assume control of the judiciary, cultural institutions and public media have raised fears of Law 2.0 being a veiled attempt to do the same to higher education. It does not help build public trust that independent agencies disburse less than half of the country's research budget. For Law 2.0 to maintain legitimacy in the eyes of the major stakeholders, the activities of the two funding agencies would need be scaled up, keeping in mind the findings of a UNESCO study that middle-income countries have tended to benefit more from translational than from basic research (Schaaper, 2014).

As far as the aim of fostering marketable skills, the new law appears to concede to the values of the academic community by continuing to 
uphold the greater prestige of academic programs and disciplines, and channeling a powerful stream of funding towards traditional universities. This move appears problematic towards the goal of producing employable graduates as these institutions appear in this study to be the carriers of "DNA" divergent from what the state would wish to reproduce. Yet long as the economy stays vibrant under the wide stream of European Union funding, and graduates enter easily into an employee's market, skills mastered at academic institutions will likely to be perceived as sufficient to the current situation. Law 2.0 thus opens up the opportunity for traditional universities to prove true to the claim that critical thinking, "soft skills" and habits of lifelong learning matter more in a $21^{\text {st }}$ century economy than the possession of a specific skill currently prioritized by employers. What the law does not do is incentivize these outcomes in any way, as institutions and thus individual academics are to be evaluated on the basis of producing quantifiable knowledge.

Finally, the impact of Law 2.0 is likely to be blurred by the mere the pace of legislative change in Polish higher education in recent years, which has produced a strong sense of "reform fatigue." The academic community has struggled to keep pace with the new regulations and directives. Each successive reform effort deepened the perception that the previous one was incomplete and underdeveloped, and that new solutions were not allowed to ripen or bear fruit before being superseded by even newer mechanisms. Whether this perception is accurate or not, the mere perception increases the likelihood that further reforms of the existing system in the near future would be resented, evaded and even subverted on the ground.

\section{Conclusions}

Social systems tend to generate the outcomes they were designed for. According to the systems theorist Richard Buckminster Fuller, "You never change things by fighting the existing reality. To change something, build a new model that makes the existing model obsolete" (Fuller, 2019). The organizational "DNA" proscribing the self-generation of the university as a social institution in the service of truth remains incredibly resilient (Lenartowicz, 2015) - a fact confirmed over and over again in studies of academic staff. Tenets of disinterested truth and academic self-governance have been the rallying cry of academics in the Czech Republic (Pabian et al., 2011), Germany (Krücken, 2003; Pritchard, 2004), Italy (Tavoletti, 2010), Austria (Pechar, 2012), and Poland (Shaw, 2018). As Shaw \& Lenartowicz (2016) have noted, governments and reformers who attempt to forge a different identity for European universities contend not only with a powerful tradition associated with Wilhelm von Humboldt, but also with decades of research showing that reforms of higher education institutions in general have been notoriously difficult to institute, and they usually fail (Hotho, 2013; Wildavsky et al., 2011; Psacharopoulos, 1989; Clark, 1986; Levine, 1980). Maassen and Olsen (2007) posited that when reforms in higher education do fail, it is when conflicting institutional logics - or "rationalized myths" - create turmoil, contestation and inertia. Such appears to be the Polish case, with ample evidence of compensatory behavior of dubious value towards the achievement of either set of most desirable ends.

These findings occasion a word of warning regarding policies that assume the historically grounded institution of the university can be reoriented as an instrument for achieving state priorities with an optimal balance of carrots and state-of-the-art sticks - especially in a postcommunist context with an entrenched association between national and academic self-determination. From a second-order systems perspective, reforms most likely to succeed are not those that aptly balance punishments and rewards, but those that "hit" the right note in the system's root identity. In the Polish case, it appears that the institutional identity most likely to align with the "desirable ends" of social and economic development is that of Technical University (politechnika) an unsurprising finding given its profile and long-standing traditions of cooperating with industry. The finding is consistent with Stinchcombe's (1968) observation of a "correlation between the time in history that a particular type of organization was invented and the social structure of that type which exists at the present time." (p. 143). What does appear surprising is the "academic drift" of Vocational HEI, an institution established in the 1990s for the express purpose of practical training, yet aspiring to drop its adjective and be a "normal" university. In this case, it would appear that the predominance of faculty teams ("cell colonies") imported directly from Flagship University determined the replication of an earlier organizational paradigm ("DNA") rather than the creation of a new one.

The findings of this study warn that unless the distinct and resilient organizational identities of different types of HEIs are assumed by policymakers to be very real in their consequences, reform is likely to produce compensatory adaptations and "reform fatigue" rather than meaningful change. What might this mean in practice? If the only change worthy of public resources is one that shifts the pattern of identity embedded in an organization's daily, discursive self-description (Lenartowicz, 2018), the most obvious place to start would be serious investigation on organizational identity as expressed in the daily communication of its agents. In addition, if the outcome of market-relevant skills and innovations was absent from the root model of traditional universities, it is certainly a root identity of many other institutions that have so far not received equal government attention as traditional universities. In Poland, private HEIs, NGOs and foundations sprung up to fill the niche, with some developing highly innovative educational programs deserving of public support. Institutions such as these are examples of new organizational structures built up within the last twenty years to address some of the very same needs that the government has tried to pressure traditional HEIs to fulfill. Given the doubtful success of earlier approaches, policymakers might consider diversifying public investment in different types of educational structures for different purposes. There is no doubt that traditional universities still have a part to play in pushing the boundaries of knowledge and preparing broadly educated elites - that is the milk they are built to produce. Yet perhaps it is time they were no longer required to plow fields, since there are other types of HEIs with proven track-records of excellence that could prove deserving of public investment.

\section{Acknowledgements}

The author gratefully acknowledges the support of the Foundation for Polish Science (Grant 5./2015: Institutional Autonomy and the Models of Adaptation of Polish Universities to a Changing Social and Economic Environment) and the support of the principal investigator, Prof. Marek Kwiek. The author also wishes to thank Prof. David Chapman for his assistance in framing and conducting this study and Dr. Marta Lenartowicz for an introduction to the theoretical lens of autopoisesis. 
Appendix A. Coding System

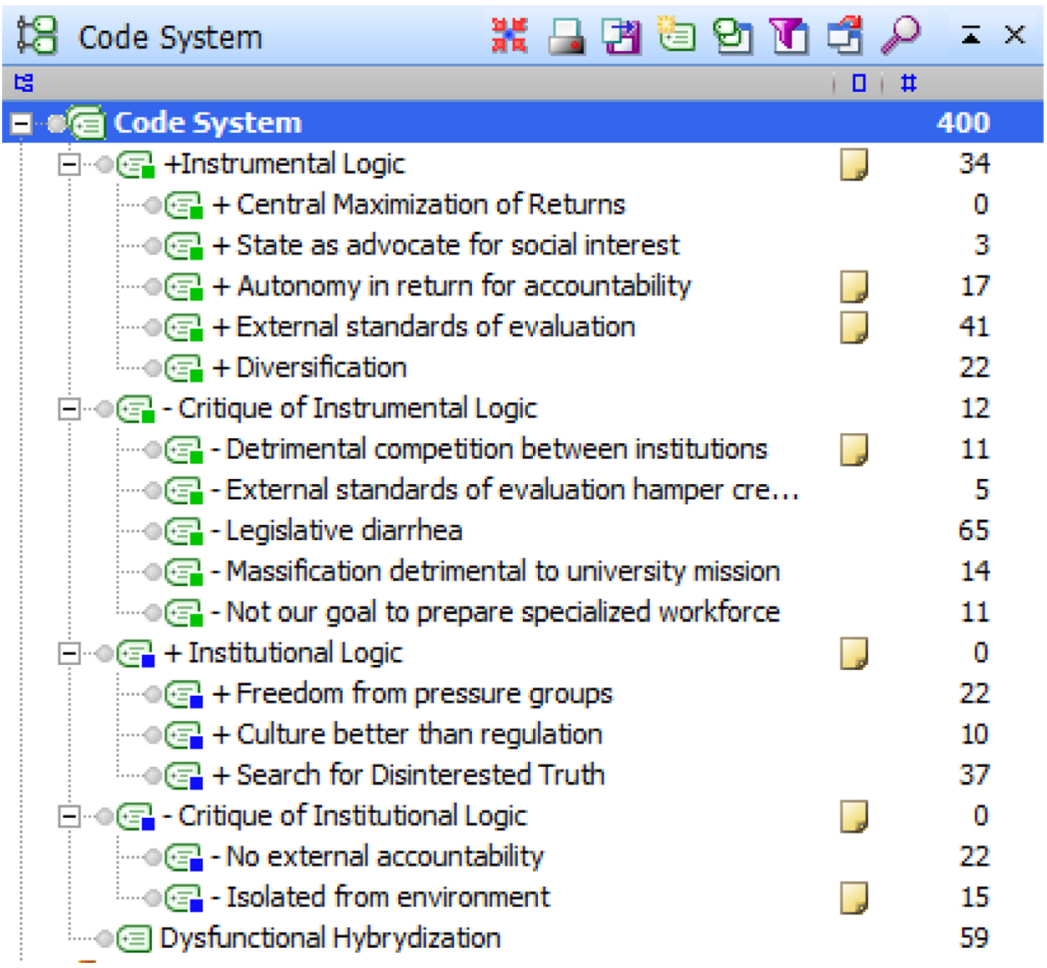

Appendix B. Visual Representation of Participant Views

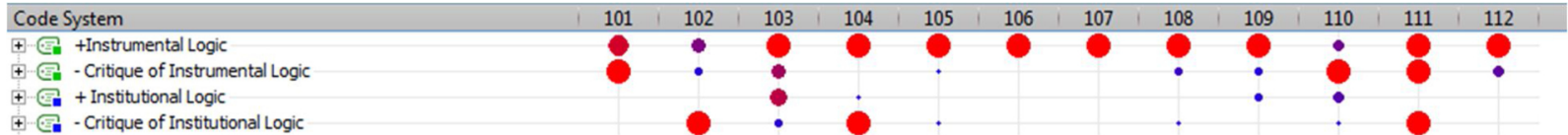

Fig. B1. Policymakers.

In the following figures, the size of the dot corresponds to the number of segments coded in a given interview. Calculation of symbol size refers to the column.

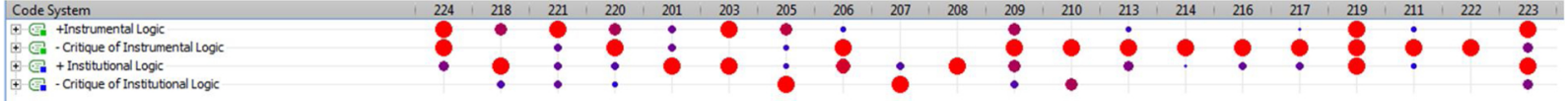

Fig. B2. Academic Leaders.

\section{References}

Agasisti, T., Catalano, G., 2006. Governance models of university systems-towards quasi-markets? Tendencies and perspectives: a European comparison. J. High. Educ. Policy Manag. 28 (3), 245-262. https://doi.org/10.1080/13600800600980056.

Bok, D., 2009. Universities in the Marketplace: The Commercialization of Higher Education. Princeton University Press, Princeton, NJ.

Braun, D., Merrien, F.X., 1999. Governance of universities and modernisation of the state: analytical aspects. In: Braun, D., Merrien, F.X. (Eds.), Towards a New Model of Governance for Universities? Kingsley, London, pp. 9-33.

Capano, G., Regini, M., 2014. Governance reforms and organizational dilemmas in European universities. Comp. Educ. Rev. 58 (1), 73-103.

Clark, B.R., 1986. The Higher Education System: Academic Organization in CrossNational Perspective. University of California Press, Berkeley, CA.

Dobbins, M., Knill, C., 2009. Higher education policies in Central and Eastern Europe: convergence toward a common model? Governance 22 (3), 397-430.

Dobbins, Michael, 2011. Higher Education Policies in Central and Eastern Europe: Convergence Towards a Common Model? Palgrave Macmillan, Houndmills,
Basingstoke, Hampshire; New York.

Dobbins, Michael, 2017. Exploring higher education governance in Poland and Romania: re-convergence after divergence? Eur. Educ. Res. J. 16 (5), 684-704. https://doi.org/ $10.1177 / 1474904116684138$.

European Social Survey. (2018, January 25). Retrieved January 25, 2018, from http:// www.europeansocialsurvey.org/.

Fuller, B. (n.d.). The countdown begins. Retrieved from https://www.bfi.org/ideaindex/ projects/2015/greenwave.

Geertz, C., 1973. The Interpretation of Cultures. Basic Books.

Gornitzka, A., Maassen, P., 2000. Hybrid steering approaches with respect to European higher education. High. Educ. Policy 13 (3), 267-285.

Gornitzka, Å., Maassen, P., 2017. European Flagship universities: autonomy and change. High. Educ. Q. 71 (3), 231-238. https://doi.org/10.1111/hequ.12130.

Gornitzka, A., Maassen, P., Olsen, J.P., Stensaker, B., 2007. "Europe of Knowledge:" Search for a New Pact. University dynamics and European integration, pp. 181-214.

Heinze, T., Knill, C., 2008. Analysing the differential impact of the Bologna process: theoretical considerations on national conditions for international policy convergence. High. Educ. 56 (4), 493-510.

Hotho, S., 2013. Higher education change and its managers: alternative constructions. 
Educ. Manag. Adm. Leadersh. 41 (3), 352-371. https://doi.org/10.1177/ 1741143212474806.

Katz, D., Kahn, R.L., 1966. Organizations and the system concept. The Social Psychology of Organizations. John Wiley \& Sons, New York, pp. 14-29.

King, R.P., 2007. Governance and accountability in the higher education regulatory state. High. Educ.: Int. J. High. Educ. Educ. Plann. 53 (4), 411-430.

Krücken, G., 2003. Learning the 'New, New Thing': on the role of path dependency in university structures. High. Educ. 46 (3), 315-339. https://doi.org/10.1023/ A:1025344413682.

Kulczycki, E., 2017. Assessing publications through a bibliometric indicator: the case of comprehensive evaluation of scientific units in Poland. Res. Eval. 26 (1), 41-52. https://doi.org/10.1093/reseval/rvw023.

Kwiek, M., 2012. Higher education reforms and their socio-economic contexts: shifting funding regimes and competing social narratives. In: Kwiek, M., Maassen, P. (Eds.) National Higher Education Reforms in a European Context: Comparative Reflections on Poland and Norway. Peter Lang., Bern, pp. 155-176.

Kwiek, M., 2015. The unfading power of collegiality? University governance in Poland in a European comparative and quantitative perspective. Int. J. Educ. Dev. 43, 77-89. https://doi.org/10.1016/j.ijedudev.2015.05.002.

Lenartowicz, M., 2015. The nature of the university. High. Educ. 69 (6), 947-961. https://doi.org/10.1007/s10734-014-9815-0.

Lenartowicz, M., 2018. Financing organizational changes from without: a valid instrument or a costly illusion of strategic public policy? J. Account. Organ. Change 14 (1), 99-116. https://doi.org/10.1108/JAOC-12-2016-0083.

Levine, A., 1980. Why Innovation Fails: The Institutionalization and Termination of Innovation in Higher Education. SUNY Press, New York.

Luhmann, N., 2009. Self-organization and autopoiesis. In: Clarke, B., Hansen, M.B.N. (Eds.), Emergence and Embodiment: New Essays on Second-Order Systems Theory, pp. 143-156.

Maassen, P.A., Olsen, J.P. (Eds.), 2007. University Dynamics and European Integration. Springer.

Magalhaes, R., Sanchez, R., 2009. Autopoiesis in Organization Theory and Practice. Emerald Group Publishing, Bingley.

Marginson, S., 2018. High participation systems of higher education. In: Cantwell, B., Marginson, S., Smolentseva, A. (Eds.), High Participation Systems of Higher Education. Oxford University Press, Oxford, pp. 3-38.

Menzel, H., 1978. Meaning: who needs it? In: Brenner, M., Marsh, P., Brenner, M. (Eds.), The Social Contexts of Method. St. Martin's Press, New York, pp. 140-171.

Meyer, J.W., Rowan, B., 1977. Institutionalized organizations: formal structure as myth and ceremony. Am. J. Sociol. 340-363.

Olsen, J.P., 2007. The institutional dynamics of the European university. In: Maassen, P., Olsen, J.P. (Eds.), University Dynamics and European Integration. Springer, Dordrecht, pp. 25-53.

Pabian, P., Sima, K., Kyncilova, L., 2011. Humboldt goes to the labour market: how academic higher education fuels labour market success in the Czech Republic. J. Educ. Work. 24 (1-2), 95-118.

Pechar, H., 2012. The decline of an academic oligarchy. The Bologna process and 'Humboldt's last warriors'. In: Curaj, A., Scott, P., Vlasceanu, L., Wilson, L. (Eds.), European Higher Education at the Crossroads. Springer, Netherlands, pp. 613-630. Retrieved from http://link.springer.com/chapter/10.1007\%2F978-94-007-3937-6_ 33\#page- 1 .

Péteri, G., 2000. On the legacy of state socialism in academia. In: David-Fox, M., Péteri, G. (Eds.), Academia in Upheaval: Origins, Transfers, and Transformations of the Communist Academic Regime in Russia and East Central Europe. Bergin \& Garvey, Westport, CT, pp. 275-302.

Poland, 2010. Założenia do nowelizacji ustawy - Prawo o szkolnictwie wyższym oraz ustawy o stopniach naukowych i tytule naukowym oraz o stopniach i tytule w zakresie sztuki. (Proposal of reform to The Act on Academic Degrees and Title and on Degrees and Title in Art of 23rd March 2003.). Ministry of Science and Higher Education, Warsaw.
Poland, 2018. Ustawa z dnia 20 lipca 2018: Prawo o szkolnictwie wyższym i nauce (Statute from 20 July 2018: Law on Higher Education and Science), Pub. L. No. 1668, 1. Retrieved from http://konstytucjadlanauki.gov.pl/content/uploads/2018/08/kdn. pdf.

Polish Graduate Tracking System, 2018. Retrieved April 4, 2018, from http://ela.nauka. gov.pl/en/.

Pritchard, R., 2004. Humboldtian values in a changing world: staff and students in German universities. Oxf. Rev. Educ. 30 (4), 509-528.

Psacharopoulos, G., 1989. Why educational reforms fail: a comparative analysis. Int. Rev. Educ. 35 (2), 179-195. https://doi.org/10.1007/BF00598437.

Ramirez, F., Tiplic, D., 2014. In pursuit of excellence? Discursive patterns in European higher education research. High. Educ. 67 (4), 439-455. https://doi.org/10.1007 s10734-013-9681-1. 00181560.

Gazeta Wyborcza (2013, October 1). Rektor UW na inauguracji roku: "Uniwersytet to nie firma" (Rector of Warsaw University at the inauguration:' The university is not a firm').Retrieved from http://m.warszawa.gazeta.pl/warszawa/1,106541,14706069, Rektor UW na inauguracji_roku_Uniwersytet to nie.html.

Schaaper, M., 2014. The case for graduate education: does university-based research really lead to national economic development? Montreal In: Chapman, D.W., Chien, C.-L. (Eds.), Higher Education in Asia: Expanding Out, Expanding up. UNESCO Institute for Statistics, Montreal, pp. 49-64.

Schriewer, J., 2009. "Rationalized myths" in European higher education: the construction and diffusion of the bologna model. Eur. Educ. 41 (2), 31-51.

Schwandt, T.A., 2000. Three epistemological stances in qualitative inquiry: interpretivism, hermeneutics, social constructivism. In: Denzin, N.K., Lincoln, Y.S. (Eds.), Handbook of Qualitative Research, 2nd ed. Sage, Thousand Oaks, CA, pp. 189-213.

Seidl, D., 2016. Organisational Identity and Self-Transformation: An Autopoietic Perspective. Routledge.

Shaw, M.A., 2018. Public accountability versus academic independence: tensions of public higher education governance in Poland. Studies in Higher Education. https:// doi.org/10.1080/03075079.2018.1483910.

Shaw, M.A., Lenartowicz, M., 2016. Humboldt is (not) dead: A social systems perspective on reforming European universities. In: Wie Bildung organisiert wird (Ed.), Soziologische Analysen zu Schule, Berufsbildung, Hochschule und Weiterbildung. (How education gets organized: Sociological analyses of schools, vocational, higher, and continuing education. BeltzJuventa Verlag, Weinheim/Munchen, pp. 272-274.

Simonová, N., Antonowicz, D., 2006. Czech and polish higher education-from bureaucracy to market competition. Czech Sociol. Rev. 42 (3), 517-536.

Stinchcombe, A., 1968. Social structure and organizations. In: March, J. (Ed.), Handbook of Organizations. Rand McNally, Chicago, pp. 142-193.

Sztompka, P., 1993. Civilizational incompetence: the trap of post-communist societies. Z. Soziol. 22 (2), 85-95.

Tavoletti, E., 2010. Matching higher education with the labour market in the knowledge economy: the much-needed reform of university governance in Italy. Ind. High. Educ. 24 (5), 361-375 https://doi.org/Article.

Thomas, W.I., Znaniecki, F., 1927. The Polish Peasant in Europe and America. Alfred A. Knopf, New York.

Trakman, L., 2008. Modelling university governance. High. Educ. Q. 62 (1-2), 63-83. https://doi.org/10.1111/j.1468-2273.2008.00384.x.

Von Bertalanffy, L., 1968. General System Theory: Foundations, Development, Applications. George Braziller, Inc., New York.

Wildavsky, B., Kelly, A.P., Carey, K., Harvard University, G. S. of E, 2011. Reinventing Higher Education: The Promise of Innovation. Harvard Education Press.

World Bank, 2017. World Development Indicators | Data. Retrieved January 29, 2018, from https://data.worldbank.org/data-catalog/world-development-indicators.

Zha, Q., 2009. Diversification or homogenization in higher education: a global allomorphism perspective. High. Educ. Eur. 34 (3-4), 459-479.

Zysiak, A., 2016. Punkty za pochodzenie: Powojenna modernizacja i uniwersytet w robotniczym mieście (Points for social background: Post-war modernization and the university in a working-class city). Nomos, Krakow. 